\title{
Clonal Propagation of Thespesia populnea (L.) Soland ex Correa
}

\author{
Kannan CS Warrier*, M. Anandha Prabhakaran and K.S. Venkataramanan \\ Institute of Forest Genetics and Tree Breeding, Forest Campus, Coimbatore, Tamil Nadu, India \\ *Corresponding author: kannan@icfre.org (ORCID ID: 0000-0002-5793-6139)
}

Paper No. 915

Received: 24-06-2021

Revised: 25-08-2021

Accepted: 03-09-2021

\begin{abstract}
Clonal propagation was attempted in Thespesia populnea. Among the four rooting media used, namely pallam sand, potting mixture, vermiculite, and composted coir pith, pallam sand was the most effective one. Among the four different hormone treatment combinations (1000, 2000,3000, and $4000 \mathrm{mg} \mathrm{l}^{-1}$ of IBA), IBA at $3000 \mathrm{mg} \mathrm{l}^{-1}$ was promising for this species. Composted coir pith failed to produce any response. Under in vitro conditions, direct shoot and root formation were noticed in MS medium or Woody Plant Medium containing BAP $\left(1.0 \mathrm{mg} \mathrm{l}^{-1}\right)$ and IAA $\left(0.1 \mathrm{mg} \mathrm{l}^{-1}\right)$.
\end{abstract}

HIGHLIGHTS

(- Thespesia populnea is amenable for clonal propagation

Keywords: Thespesia populnea, Portia tree, clonal propagation, vegetative propagation

Thespesia populnea (L.) Soland ex Correa belongs to the Malvaceae family and is commonly referred as Portia Tree. The name Thespesia is derived from the Greek word thespesios, which means divine or sacred (Troup 1921). It is a valued multipurpose tree species suitable for planting outside forest areas. It is a small evergreen tree that averages $6-12 \mathrm{~m}$ in height with a short, often crooked stem and abroad, dense crown. In ancient times, trees were planted around places of worship. The species has been planted throughout the tropics and is naturalized in tropical climates throughout the world. (Friday and Okano 2005; Fosberg and Sachet 1972). It is a common species in the coastal tracts of the Indian Peninsula and mangrove swamps. Cultivated occasionally in Central and South America (Francis 2004). It is widespread and perhaps wild in South Kanara, Malabar, deltas of Godavari and Mahanadi, and in Cuttack. It is also found in the Sunderbans of West Bengal and in Andaman. It is a promising candidate for avenue planting. It is timber of great local utility used for furniture, agricultural implements, and small canoes. It is an easy timber to saw and work. It can be brought to a smooth surface and takes a high polish. Wood is highly valued in Kerala because it does not split. The wood is highly resistant to dry wood termites. The wood can be carved into bowls, tools, and figures. Timber is in demand for turnery and toys. It is also suitable for helves, tool handles, shuttles, and other textile accessories. Wood is used for food containers, slit drums, and cabinetry. It is also used as fuelwood. Most of the plant parts are being used for medicinal purposes. It is a magnificent agroforestry species also. Leaves are used as manure. It is relished by cattle too. Since ancient times, the tree has been planted in home gardens. It is used to stabilize bunds of ponds for prawn cultivation. The species has been used as a living fence post also (Harikrishnan and Ramesh 1993). It is an excellent windbreak in coastal areas due to its dense crown and tolerance to wind and

How to cite this article: Warrier, K.C.S., Prabhakaran, M.A. and Venkataramanan, K.S. 2021. Clonal Propagation of Thespesia populnea (L.) Soland ex Correa. IJAEB, 14(03): 325-327.

Source of Support: None; Conflict of Interest: None (क) 
salt spray. It is being used as a standard for pepper vines (Ceccolini 2002). Thespesia is an integral component of the home gardens of south Kerala. One added advantage of this species is that it can withstand salinity and waterlogging (Iqbal et al. 2002). In India, Thespesia populnea wood may fetch up to ₹ $1500 /-$ per sq.ft.

Clonal strategy is an excellent approach to eliminate inbreds, provide adapted clones, produce valuable genotypes, control genetic diversity, and, more importantly, help predict yield in plantation programs. Clonal forestry has been proved to increase the productivity of species like Eucalypts, Acacias, Poplars, Paulownia, and several other species in different parts of the world. Since considerable variations are observed in plantations raised through seeds, clonal forestry is the answer for the mass production of end-use specific uniform planting materials. Generally, in horticultural and forestry methods, propagation is done by using different cuttings like stem cuttings, leaf cuttings, root cuttings, layering, and grafting. Rooting of stem cuttings depends on size, auxin concentrations, and rooting medium. Rooting will be different for different growth media like different types of soil, vermiculite, and coir pith. Therefore, an attempt was made in standardizing the clonal propagation in Thespesia populnea.

\section{MATERIALS AND METHODS}

The experiment was conducted at the Institute of Forest Genetics and Tree Breeding, Coimbatore.

Plant Material: Leafy and stem cuttings of approximately 8 to $10 \mathrm{~cm}$ from the selected Thespesia populnea tree using a secateur.

Rooting Media: Four types of rooting media were prepared for stem cuttings; namely, Pallam sand, Potting mixture (Red soil: Pallam sand: River sand (0.5: 2: 1)), Vermiculite and Composted coir pith.

Treatments: Collected cuttings were treated with $0.2 \%$ Bavistin for 15 minutes to avoid fungal contamination. Different concentrations of rooting hormone indole-3-butyric acid (IBA) used were $1000,2000,3000$, and $4000 \mathrm{mg} \mathrm{l}^{-1}$. A combination without the hormone was served as control. After dipping the cut end of the explants in the hormone mixed with talcum powder, they were placed in root trainers containing respective media and kept in the polytunnel for rooting. Rooted plantlets were shifted from the polytunnel to the shade house with $75 \%$ shade after 21 days for hardening. 50 cuttings in five replications were used per treatment.

Polytunnels: Cost-effective tunnels of size $180 \mathrm{~cm}$ $\times 90 \mathrm{~cm} \times 70 \mathrm{~cm}$ made of M.S. Rod covered with transparent polythene sheets of 400 gauge was used for rooting of cuttings. High humidity of 8590 per was maintained in such polythene tunnels, provided they were kept closed airtight over a moist well-drained sand bed. The area was kept clean without decaying organic matter to avoid contamination. Waterlogging around the polytunnel was avoided. A layer of shade net was found ideal over the tunnels to control the temperature rise. A window was provided to the tunnel to spray water 4-5 times a day to maintain a thin film of water over the cuttings. The frequency of spray, was reduced during rainy days. Dead and decaying cuttings found if any in the polytunnels were removed immediately along with the root trainer.

Water Culture: Collected cuttings were treated with $0.2 \%$ of Bavistin for 15 minutes, and the cut end was dipped in rooting hormone indole-3-butyric acid (IBA) 100 and $200 \mathrm{mg} \mathrm{l}^{-1}$ concentration for 12 hours. Then explants were transferred to plain water for rooting and kept in the shade house. Water was changed every day.

Tissue Culture: Murashige and Skoog medium and Woody Plant Medium with different concentrations of BAP and IAA were used for in vitro propagation.

Design: The experiment was laid out in a Completely Randomized Design.

\section{RESULTS AND DISCUSSION}

The results of the study are presented in Table 1.

Table 1: Effect of various rooting media and hormone combinations in clonal propagation of Thespesia populnea

\begin{tabular}{llll}
\hline $\begin{array}{l}\text { Rooting } \\
\text { Media }\end{array}$ & $\begin{array}{l}\text { IBA } \\
\text { Concentration } \\
\text { (mg l-1 }^{-1}\end{array}$ & $\begin{array}{l}\text { Rooting } \\
\text { Percentage }\end{array}$ & $\begin{array}{l}\text { Number of } \\
\text { roots }\end{array}$ \\
\hline Pallam Sand & 1000 & 0 & 0 \\
Pallam Sand & 2000 & 30 & 12 \\
Pallam Sand & 3000 & 78 & 26 \\
Pallam Sand & 4000 & 50 & 18 \\
Pallam Sand & Control & 10 & 16
\end{tabular}




\begin{tabular}{|c|c|c|c|}
\hline $\begin{array}{l}\text { Potting } \\
\text { Mixture }\end{array}$ & 1000 & 25 & 17 \\
\hline $\begin{array}{l}\text { Potting } \\
\text { Mixture }\end{array}$ & 2000 & 33 & 31 \\
\hline $\begin{array}{l}\text { Potting } \\
\text { Mixture }\end{array}$ & 3000 & 66 & 34 \\
\hline $\begin{array}{l}\text { Potting } \\
\text { Mixture }\end{array}$ & 4000 & 25 & 22 \\
\hline $\begin{array}{l}\text { Potting } \\
\text { Mixture }\end{array}$ & Control & 0 & 0 \\
\hline Vermiculite & 1000 & 50 & 5 \\
\hline Vermiculite & 2000 & 45 & 5 \\
\hline Vermiculite & 3000 & 68 & 6 \\
\hline Vermiculite & 4000 & 39 & 5 \\
\hline Vermiculite & Control & 0 & 0 \\
\hline $\begin{array}{l}\text { Composted } \\
\text { Coir Pith }\end{array}$ & 1000 & 0 & 0 \\
\hline $\begin{array}{l}\text { Composted } \\
\text { Coir Pith }\end{array}$ & 2000 & 0 & 0 \\
\hline $\begin{array}{l}\text { Composted } \\
\text { Coir Pith }\end{array}$ & 3000 & 0 & 0 \\
\hline $\begin{array}{l}\text { Composted } \\
\text { Coir Pith }\end{array}$ & 4000 & 0 & 0 \\
\hline $\begin{array}{l}\text { Composted } \\
\text { Coir Pith }\end{array}$ & Control & 0 & 0 \\
\hline
\end{tabular}

Rooting was observed at 21 days after placing the cuttings in the polytunnels. IBA at $3000 \mathrm{mg}$ $1^{-1}$ induced $78 \%$ rooting in pallam sand, $66 \%$ in potting mixture, and $68 \%$ in vermiculite. Rooting in composted coir pith media was nil. Considering the cost factor, pallam sand may be selected for rooting of cuttings in Thespesia populnea. Considering the different concentrations of IBA, $3000 \mathrm{mg} \mathrm{l}^{-1}$ was found to be superior. Composted coir pith failed to initiate rooting for Thespesia populnea in all different concentrations of IBA. This shows that composted coir pith is not a suitable medium for Thespesia populnea. Rooting in control was very poor or nil.

A cost-effective water culture technique for rooting could be developed for Thespesia populnea during the current study. Leafy cuttings could be rooted in ordinary drinking water using this method. The success rooting was up to 60 per cent for leafy cuttings in $100 \mathrm{mg} \mathrm{l}^{-1}$ and $200 \mathrm{mg} \mathrm{l}^{-1}$ IBA. With respect to root length, number of roots, and shoot length, $100 \mathrm{mg} \mathrm{l}^{-1}$ IBA was more effective than 200 $\mathrm{mg} \mathrm{l}^{-1}$ IBA. A decreasing trend in rooting parameters could be observed with increased IBA concentration (Warrier 2011). Leafy cuttings exhibited superiority over stem cuttings when rooting was attempted in vermiculite.
Fungicidal application with bavistin $(0.1 \%)$ for 10 days reduced the fungal contamination substantially in tissue culture conditions. Treating the explants with $0.1 \%$ mercuric chloride for three minutes was the best surface sterilization method with maximum culture response. Mercuric chloride treatment for the lower duration (less than 3 minutes) and longer duration (12 minutes) did not yield desired results. Both Murashige and Skoog (MS) medium and Woody Plant Medium (WPM) containing BAP (1.0 $\mathrm{mg}^{-1}$ ) resulted in giving bud sprout in Thespesia populnea. BAP $\left(2.0 \mathrm{mg} \mathrm{l}^{-1}\right)$ failed to give any response even after 17 days. Direct shoot and root formation was noticed in MS medium containing BAP $(1.0 \mathrm{mg}$ $\left.\mathrm{l}^{-1}\right)$ and IAA $\left(0.1 \mathrm{mg} \mathrm{l}^{-1}\right)$ and WPM with BAP $(1.0 \mathrm{mg}$ $\left.\mathrm{l}^{-1}\right)$ and IAA $\left(0.1 \mathrm{mg} \mathrm{l}^{-1}\right)$. Browning of the medium due to polyphenol interference was overcome by transferring the explants to new culture tubes until the browning disappeared.

\section{REFERENCES}

Ceccolini, L. 2002. The homegardens of Soqotra island, Yemen: an example of agroforestry approach to multiple land-use in an isolated location. Agrofor Sys., 56(2): 107-115.

Fosberg, F.R. and Sachet, M.H. 1972. Thespesia populnea (L.) Solander ex Correa and Thespesia populneoides (Roxburgh) Kosteletsky (Malvaceae). Smithsonian Contributions to Botany. No. 7, pp. 13.

Francis, J.K. 2004. Thespesia populnea (L). Sol.ex Correa. International Institute of Tropical Forestry, USDA. Available on the web http://www.rngr.net/Publications/ ttsm/Folder.2003-07-11.4726/PDF.2004-03-16.0354/file. Last Accessed on 14 ${ }^{\text {th }}$ February, 2021.

Friday, J.B. and Okano, D. 2005. Thespesia populnea (milo). Species profiles for Pacific Island Agroforestry. Available on the web www.traditionaltree.org. Last Accessed on 04 $4^{\text {th }}$ January, 2021.

Harikrishnan, M. and Ramesh, R. 1993. Coastal agroforestry and its sustainable utilisation. In: Sustainable management of coastal ecosystems (Ed. Swaminathan, M.S.) M.S. Swaminathan Research Foundation/Institute for Ocean Management, Anna University; Madras; India.

Iqbal, M.Z, Yasmin, N. and Shafiq, M. 2002. Salt tolerance variation in some common trees. Acta Bot Hung., 44(1-2): 67-74.

Troup, R.S. 1921. The Silviculture of Indian Trees. Volume 1 (Revised and enlarged edition). Controller of Publications, Delhi, pp. 297-300.

Warrier, K.C.S. 2011. Developing Cloning Techniques for Raising High Yielding Clonal Plantation of Casuarina equisetifolia L. Project Completion Report. Institute of Forest Genetics and Tree Breeding. (Indian Council of Forestry Research and Education), Coimbatore, pp. 64. 
